\title{
A simple relationship between cloud drop number concentration and precursor aerosol concentration for the regions of Earth's large marine stratocumulus decks
}

\author{
D. A. Hegg ${ }^{1}$, D. S. Covert ${ }^{1}$, H. H. Jonsson ${ }^{2}$, and R. K. Woods ${ }^{2}$ \\ ${ }^{1}$ Department of Atmospheric Sciences, University of Washington, Seattle, WA, USA \\ ${ }^{2}$ Meteorology Department, Naval Post Graduate School, Monterey, CA, USA
}

Correspondence to: D. A. Hegg (deanhegg @ atmos.washington.edu)

Received: 12 October 2011 - Published in Atmos. Chem. Phys. Discuss.: 25 October 2011

Revised: 11 January 2012 - Accepted: 19 January 2012 - Published: 1 February 2012

\begin{abstract}
Aircraft-based measurements of cloud condensation nuclei $(\mathrm{CCN})$, accumulation mode and Aitken mode number concentrations, cloud drop number concentration (CDNC), and selected ancillary measurements are presented for the three large, semi-permanent marine stratocumulus decks of the earth (in the Pacific offshore of California and Chile and in the Atlantic offshore of Namibia). Based on these data, a simple linear relationship between CDNC and the accumulation mode number concentration (AMNC) is derived via regression. The slope of the regression is $0.72 \pm 0.04$ with an $R^{2}$ of 0.90 , higher than those found for CDNC-CCN linear regressions. Explanations of the relatively favorable CDNC-AMNC relationship and its utility for climate studies are discussed.
\end{abstract}

\section{Introduction}

A key linkage in the concatenation of physical relationships that constitute the indirect radiative forcing of climate by aerosols is the dependence of cloud drop number concentration (CDNC) on the properties of the aerosol on which the drops form (IPCC, 2001, 2007). Hence, much effort has been expended on delineating the aerosol properties that render the particles effective as cloud condensation nuclei (CCN). Of course, the CCN activity of aerosols has been directly measured for many years (e.g., Hudson, 1983; Roberts et al., 2006) but such measurements are quite difficult and subject to large errors (Chuang et al., 2000; McFiggans et al., 2006). Consequently, even now such measurements are relatively sparse and lack the global coverage necessary to effectively address global climate issues (Bellouin et al., 2009). Furthermore, CCN activity in itself does not offer information on the sources of the aerosol (for example whether natural or anthropogenic), which is a key question for climate change analysis. It is for this reason that numerous studies, commonly called "CCN closure studies", have tried to link CCN activity to such aerosol properties as size and composition (e.g., Juranyi et al., 2010; Dusek et al., 2010). Perhaps still more importantly, even if the $\mathrm{CCN}$ activation spectrum of the aerosol is fully defined, there is not, in principle, sufficient information in this alone to predict CDNC. Accompanying information on the supersaturations to which the aerosol will be exposed is equally necessary and this is a complex function of cloud dynamics and the $\mathrm{CCN}$ activity itself (Twomey, 1959; Pringle et al., 2009; Hudson et al., 2010). Indeed, within global climate models $\mathrm{CCN}$ activity or even the aerosol size distribution is not commonly carried as a prognostic variable and the supersaturation is rarely if ever carried (Pringle et al., 2009).

In consideration of these issues, particularly the need for large scale coverage with its implied mandate for remote retrieval of aerosol properties that can predict CDNC, numerous studies have explored possible simplifications to the aerosol-CDNC relationship, for example using such parameters as size dependent hygroscopicity (e.g., Petters and Kreidenweiss, 2008; Henning et al., 2010). A particularly simplified relationship has been suggested by the study of Dusek et al. (2006). Based on extensive measurements in Germany, the authors propose that particle size alone can explain most of the variance in $\mathrm{CCN}$ concentrations $(\sim 90 \%)$. Such a simplification would be a boon to climate change studies, offering some justification for the empirical relationships used in many global models. However, Hudson (2007) has pointed out that such a simple CCN activity aerosol relationship cannot be valid for all venues, giving as a counter example a marine data set, and Pringle et al. (2009) have estimated that substantial errors would result from the use of any single such relationship if applied globally. 
Nevertheless, the value of such a simplified relationship as that proposed by Dusek et al. (2006), with its implied simple relationship between aerosols and CDNC, is tantalizing, not only from the standpoint of model usage but from that of remote sensing. Such parameters as, for example, the accumulation mode number concentration, are readily available from existing remote retrieval algorithms such as that for MODIS (Remer et al., 2005) and have a substantial validation history. In contrast, algorithms to retrieve $\mathrm{CCN}$ activity, while available, have been little used and then with very modest success (e.g., Gasso and Hegg, 2003). Indeed, a recent assessment by Kapustin et al. (2006) suggests that effective remote retrieval of CCN activity will be very challenging. It therefore seems worthwhile to pursue a simple empirical CDNC-aerosol relationship, such as that implied by the Dusek et al. (2006) study, a bit further. In this study, we examine data on cloud microphysics and aerosol properties for selected venues of most importance to indirect aerosol forcing of climate, seeking such a relationship.

\section{Venues}

To avoid the problem of trying to fit a single simple CDNCaerosol relationship to widely diverse environments, as discussed by Pringle et al. (2009), the possibility of selecting a particular cloud regime that would be highly significant from the standpoint of global indirect aerosol radiative forcing should be explored. Fortunately, such a regime comes readily to mind. It is now widely accepted that anthropogenic aerosols can have a significant impact on the albedo of the extensive subtropical marine stratocumulus decks that occur off the west coasts of Africa, and South and North America (e.g., Platnick and Twomey, 1994; Durkee et al., 2000; Huneuus et al., 2006; Keil and Haywood, 2003; Allen et al., 2011). Indeed, they are influenced by a variety of aerosol sources including industrial pollution, biomass burning, and marine emissions (cf., Hegg et al., 2010; Chand et al., 2010; Haywood et al., 2003). These decks are a major factor in the radiative balance of the atmosphere (Klein and Hartmann, 1993) and, due to a combination of cloud extent, frequency, and the cloud-type dependent sensitivity of cloud albedo to aerosol modulation, the climatic impact of aerosols on cloud microphysics (the indirect effect) is largely determined by these decks (Warren et al., 1988; Platnick and Twomey, 1994; Allen et al., 2011). For example, Kogan et al. (1996) estimate the contribution of low stratiform clouds to the indirect forcing by aerosol as $\sim 60 \%$. Hence, quantifying the CDNCaerosol relationship in simple terms for these stratocumulus decks alone would have great benefit for understanding indirect aerosol radiative forcing globally.

The data examined here are derived primarily from the multi-year CARMA experiments, conducted off the California coast of North America from 2004 to 2007 (cf., Hegg et al., 2007) and the VOCALS-Rex study conducted off the Chilean coast of South America in 2008 (cf., Allen et al., 2011). Additionally, a small amount of data from the stratocumulus deck off the Namibian coast of Africa has been distilled from both the literature (e.g., Keil and Haywood, 2003) and from a data archive of the SAFARI 2000 study (University of Washington CARG archive at http://carg.atmos.washington.edu).

\section{Methodology}

All of the in situ data for the CARMA and VOCALS studies were obtained with the CIRPAS Twin Otter research aircraft (www.cirpas.org). Most of the instrumentation package available on this aircraft has been described in a number of previous publications (e.g., Hegg et al., 2007; Wang et al., 2002, 2007). The key instruments for this study, used to measure aerosol concentrations in the 0.1 to $3.0 \mu \mathrm{m}$ size range and cloud drop number concentrations respectively, were the PCASP-100 (PMS/DMT, Boulder, CO) aerosol spectrometer, and either the PMS/DMT FSSP-100 spectrometer, used for CARMA (size range of $2-40 \mu \mathrm{m}$ ), or the DMT CAPS probe, used for VOCALS (size range of $0.5-45 \mu \mathrm{m}$ ). Deadtime errors in the FSSP were eliminated by use of a DMT SPP100 pulse height analyzer and coincidence errors were corrected using the procedure of Baumgardner et al. (1985). Additionally, two different CCN spectrometers were used to obtain CCN activation spectra. For the CARMA study, both the DMT model CCN-100 CCN spectrometer and the University of Wyoming model MA-100 static diffusion chamber were utilized. For VOCALS, only the former instrument was used. All instruments were calibrated against $\left(\mathrm{NH}_{4}\right)_{2} \mathrm{SO}_{4}$ and $\mathrm{NaCl}$ test aerosols generated by a TSI model 3076 Collison atomizer (TSI, St. Paul, MN) and size classified by a differential mobility analyzer (TSI model 3071). The laser scattering probes were also calibrated against silica and PSL spheres from Duke Scientific. Finally, Aitken particle concentrations were determined as the difference between total particle concentrations as measured by a condensation particle counter with a lower size limit of $0.01 \mu \mathrm{m}$ diameter (TSI model $3010 \mathrm{CPC}$ ) and the PCASP number concentration. Hence, the size range covered is 0.01 to $0.1 \mu \mathrm{m}$. For the Namibian data, in the case of both the Keil and Haywood study and the CARG archive, the CDNC data were acquired with a FSSP-100 and the AMNC data with a PCASP-100.

The sampling plan for the data presented here consisted of obtaining vertical profiles of the various parameters just discussed from well above the cloud deck to well below it, typically to $\sim 30 \mathrm{~mm}$.s.l. At least one and commonly several such profiles were obtained on each research flight. Distances offshore for the profiles ranged from 30 to $330 \mathrm{~km}$. An example of such a profile is shown in Fig. 1 and illustrates the close connection between CDNC and AMNC. The aerosol measurements to which the overlying CDNC are compared were those obtained just below cloud base to provide the 


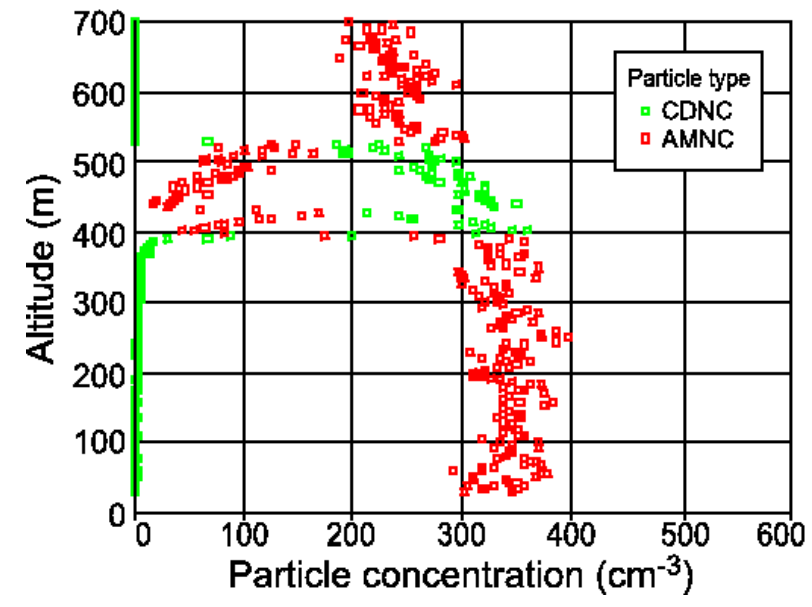

Fig. 1. Vertical profile of the accumulation mode number concentration (AMNC) and the cloud drop number concentration (CDNC) through the stratocumulus deck sampled during CARMA IV on 27 August 2005.

closest possible juxtaposition of aerosol and CDNC. Numerous studies in the stratocumulus regions have demonstrated that the CDNC is almost exclusively connected to the below cloud and not the above cloud aerosol (cf., Hudson et al., 2010; Keil and Haywood, 2003; Martin et al., 1994). This is also evident in Fig. 1. Note that all available data from the CARMA and VOCALS studies have been employed, irrespective of aerosol composition or source.

\section{Results and discussion}

Data from the vertical profiles used in the analysis are shown in Table 1. Note that the CDNC values used are the peak values measured in the profiles. This choice has been made as the most sensitive to below cloud aerosol properties (e.g., not distorted due to mixing). However, the profile data were also averaged over $5 \mathrm{~s}$ to reduce spikes due to noise so the peak value is representative. Corresponding peak cloud liquid water contents ranged from 0.15 to $0.65 \mathrm{~g} \mathrm{~m}^{-3}$ with a mean value of $0.38 \pm 0.15 \mathrm{~g} \mathrm{~m}^{-3}$.

The first CDNC-aerosol relationship examined is the dependence of the CDNC on the $\mathrm{CCN}$ number concentration. A linear regression of the $\mathrm{CDNC}$ onto the $\mathrm{CCN}$ concentration active at a supersaturation of $0.3 \%$ is shown in Fig. 2 . The supersaturation value of $0.3 \%$ was selected as most characteristic of the stratocumulus examined here based on numerous past assessments (e.g., Hudson, 1983; Roberts et al., 2006; Hegg et al., 2009). Recent work by Hudson et al. (2010) has suggested that appreciably higher supersaturations can occur when aerosol concentrations are low but for the accumulation mode aerosol concentration range for our CCN data set (180 to $675 \mathrm{~cm}^{-3}$, mean of $361 \mathrm{~cm}^{-3}$ ), $0.3 \%$ is still the most appropriate value to use. The correlation shown
Table 1. Values of the variables used in the analysis derived from the vertical profiles through the cloud decks in the three regions examined. Note that UW denotes data from the University of Washington archive (see text) while RAF denotes data from Kiel and Haywood (2003).

\begin{tabular}{lrrrrr}
\hline Locale & Flight & CDNC & AMNC & Aitken & CCN \\
& & & & & $(0.3 \%)$ \\
\hline Chile & 1016 & 500 & 600 & - & 214 \\
Chile & 1018 & 550 & 675 & 425 & 542 \\
Chile & 1019 & 475 & 550 & 225 & 546 \\
Chile & 1021 & 350 & 425 & 25 & - \\
Chile & 1022 & 400 & 475 & 25 & 342 \\
Chile & 1024 & 300 & 375 & 25 & 260 \\
Chile & 1026 & 500 & 600 & 50 & 375 \\
Chile & 1027 & 475 & 500 & 75 & 400 \\
Chile & 1029 & 300 & 300 & 25 & 230 \\
Chile & 1030 & 225 & 310 & 110 & 211 \\
Chile & 1101 & 250 & 200 & 100 & 148 \\
Chile & 1102 & 400 & 450 & 125 & 350 \\
Chile & 1104 & 250 & 275 & 55 & 230 \\
Chile & 1108 & 225 & 275 & 75 & 241 \\
Chile & 1109 & 240 & 260 & 30 & 211 \\
Chile & 1110 & 400 & 525 & 165 & 483 \\
Chile & 1112 & 350 & 500 & 60 & 488 \\
Chile & 1113 & 300 & 375 & 15 & 281 \\
Ca 2007 & 811 & 250 & 200 & 530 & 106 \\
Ca 2007 & 814 & 325 & 400 & 5600 & 700 \\
Ca 2007 & 815 & 175 & 200 & 400 & 370 \\
Ca 2007 & 818 & 200 & 275 & 2425 & - \\
Ca 2007 & 821 & 225 & 250 & 440 & 106 \\
Ca 2007 & 822 & 450 & 600 & 3900 & 300 \\
Ca 2007 & 824 & 200 & 250 & 300 & 334 \\
Ca 2007 & 825 & 250 & 225 & 175 & 360 \\
Ca 2007 & 826 & 250 & 270 & 230 & 100 \\
Ca 2007 & 827 & 340 & 350 & 600 & 256 \\
Ca 2007 & 828 & 280 & 325 & 775 & 204 \\
Ca 2005 & 810 & 350 & 475 & 725 & 369 \\
Ca 2005 & 811 & 450 & 475 & 575 & 487 \\
Ca 2005 & 813 & 280 & 400 & 230 & 400 \\
Ca 2005 & 815 & 250 & 300 & 150 & 238 \\
Ca 2005 & 816 & 200 & 180 & 40 & 149 \\
Ca 2005 & 817 & 260 & 240 & 380 & - \\
Ca 2005 & 818 & 250 & 225 & - & - \\
Ca 2005 & 819 & 200 & 180 & 120 & 80 \\
Ca 2005 & 820 & 275 & 275 & 475 & 35 \\
Ca 2005 & 822 & 250 & 225 & 65 & 90 \\
Ca 2005 & 823 & 300 & 400 & 750 & 50 \\
Ca 2005 & 825 & 300 & 460 & 300 & 307 \\
Ca 2005 & 450 & 525 & 575 & 463 \\
Namibia RAF & 907.1 & 200 & - & - \\
Namibia RAF & 907.2 & 330 & - & - \\
Namibia UW & 1830 & 50 & & \\
Namibia UW & 1837.2 & 90 & & \\
\hline & 183 & & & \\
\hline
\end{tabular}




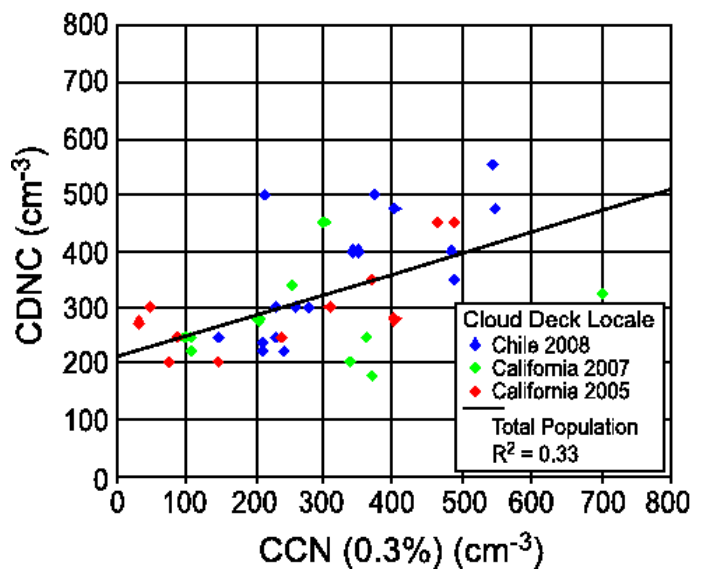

Fig. 2. Linear regression of the cloud drop number concentration (CDNC) onto the concentration of $\mathrm{CCN}$ active at $0.3 \%$ supersaturation $(\mathrm{CCN}(0.3 \%))$ from three separate studies in two of the three major stratocumulus decks on earth.

in the Figure $\left(R^{2}=0.33\right)$, while certainly highly significant, is not particularly good, suggesting that in fact most of the variance in CDNC is not explained by the variance in $\mathrm{CCN}$ $(0.3 \%)$. Regressions of CDNC onto CCN active at other supersaturations $(0.2$ to $1.0 \%)$ were still less impressive. As discussed above, this is expected and likely simply reflects the variability in supersaturations achieved in the cloud decks as well as the uncertainties in the $\mathrm{CCN}$ measurements.

As an alternative to selecting the $\mathrm{CCN}$ concentration at any particular supersaturation, a regression is next examined of the CDNC onto the total accumulation mode number concentration (AMNC). Numerous studies have pointed out that the AMNC is often a useful surrogate for effective $\mathrm{CCN}$ (i.e., the number of $\mathrm{CCN}$ actually activated). For example, Martin et al. (1994) found it to be a useful indicator of CDNC for the region around and to the north of the Azores in the North Atlantic, a region of mixed stratocumulus and cumulus clouds. Similarly, Leaitch et al. (1986) found a close relationship between AMNC and CDNC for mostly stratiform clouds (with some moderate convection) over Ontario, Canada and New York state. It has been used extensively in modeling studies (Pringle et al., 2009) and, indeed, has proven a useful surrogate for $\mathrm{CCN}$ in the venues selected here for analysis (e.g., Hegg et al., 2010; Twohy et al., 2005). Figure 3 shows this regression for data from all three stratocumulus venues (though for the Namibian deck only a few points are available: two profiles form Keil and Haywood and three from the CARG archive). The regression relationship is surprisingly strong with a slope of $0.72 \pm 0.04$ and an $R^{2}$ of 0.90 , i.e., $90 \%$ of the variance in the CDNC is explained by the AMNC. This compares very favorably with regression relationships between $\mathrm{CDNC}$ and $\mathrm{CCN}$ at any supersaturation (e.g., Hudson et al., 2010), even those that try to take into account variability in the cloud supersaturation (e.g., Hudson

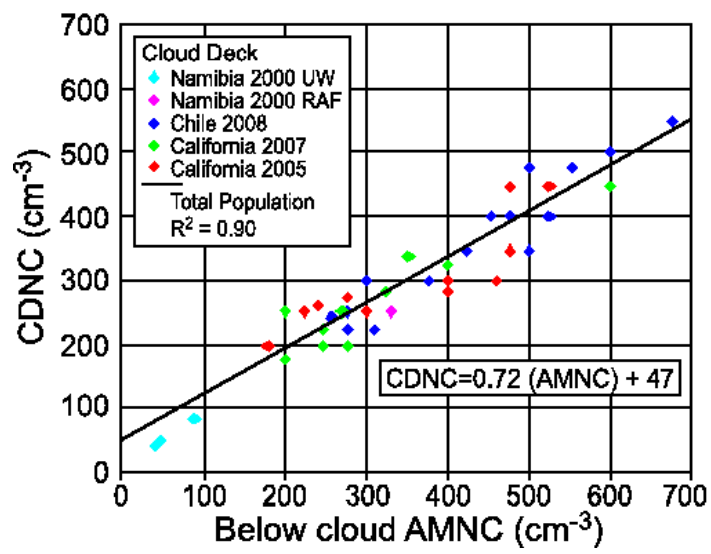

Fig. 3. Linear regression of cloud drop number concentration (CDNC) onto accumulation mode number concentration (AMNC). Data are primarily from the California and Chilean cloud decks but a few points from the Namibian deck are included as well.

and Noble, 2009). It is also noteworthy that this relationship is consistent with data from the earlier study by Twohy et al. (2005). The Twohy et al. (2005) study was conducted at a location several hundred $\mathrm{km}$ south of the CARMA operational area but was nevertheless within the region of the California Sc deck. The authors measured sub-cloud AMNC with a PCASP-100 and CDNC with a FSSP-100, i.e., the same instruments used to acquire most of the data in our analysis. Twohy et al. (2005) chose to fit their data to a nonlinear relationship (quadratic polynomial) between CDNC and AMNC, deriving a curve with an $R^{2}=0.90$. However, the data also appear able to support a good linear relationship. To explore this, we extracted values of AMNC and CDNC from Fig. 3 of Twohy et al. (2005), validating the extraction by reproducing the non-linear fit of the authors within the uncertainty of the regression coefficients and with an $R^{2}=0.89$. We then derived a linear fit of CDNC to AMNC with a slope of $0.66 \pm 0.7$, intercept of $27 \pm 15$, and $R^{2}=0.87$, i.e., a relationship that does not differ significantly from ours and which in fact provides a fit equally as good as the non-linear, three parameter fit of Twohy et al. Hence, we feel that this study supports our relationship. Similarly, a very recent study by Kleinman et al. (2012) in the VOCALS operational area found a strong correlation between AMNC and CDNC. As with Twohy et al. (2005), the authors chose a non-linear regression to characterize the AMNC-CDNC relationship but, as with Twohy et al. (2005), we estimate that a good linear fit is feasible with a slope of $\sim 0.6$ and intercept of $\sim 40 \mathrm{~cm}^{-3}$, i.e., not materially different from our relationship (based on Fig. 10 of Kleinman et al., 2012). To rationalize this relatively strong dependence of CDNC on AMNC in comparison to ostensibly more refined parameters such as $\mathrm{CCN}$, we must consider cloud drop activation from a broad perspective. 
Several years ago, Stevens and Feingold (2009) pointed out that understanding the effects of aerosols on clouds and precipitation was a particularly difficult problem due to the large number of negative feedbacks in the system. The authors label such feedbacks buffers since they consist of processes within a system that act in the opposite sense of any perturbation in system input, thus attenuating the impact of such changed input, much like a chemical buffer in solution chemistry. Such buffers tend to obscure functional dependencies. As a specific example, they pointed to the cloud drop activation process in which a reduction in the pre-cloud aerosol size distribution or composition would tend to reduce $\mathrm{CCN}$ concentrations at the lower supersaturations. This would reduce initial CDNC and would lead to locally higher supersaturations, and thus to the activation of smaller particles (e.g., Aitken mode) than would otherwise be activated. This would reduce the variation in CDNC compared to variance in the pre-cloud particle properties.

Looking more closely at this buffer, it is clear that several different particle-supersaturation linkages are possible, depending on the number size distribution and hygroscopicity of the aerosols present. This can be visualized most clearly by considering the issue as first formulated by Twomey (1959). The supersaturation achieved in-cloud is the difference between a source term for water vapor mixing ratio (essentially either adiabatic cooling due to vertical velocity or radiative cooling) and a sink term that is condensation onto activated particles. In these terms, three different CDNC-AMNC linkages seem feasible. (1) The first and simplest linkage is when the particles present are sufficiently large and hygroscopic relative to, say, the cloud updraft and consequent cooling rate that all of the aerosol particles activate $a b$ initio. Increases in the updraft will then have no impact on the CDNC. The activated cloud drops will simply grow faster as they ascend faster in the cloud. (2) A second possible linkage between CDNC, precursor aerosol and incloud supersaturation is the one most often discussed in the literature. If one reduces the number of large particles (e.g., accumulation mode) compared to the first scenario, and all of the particles have more or less the same hygroscopicity, then as supersaturation increases because of the relatively small water vapor sink term, smaller particles (e.g., Aitken mode) are activated until the sink term grows sufficiently to halt increase in the supersaturation. These additional smaller particles act as a buffer to compensate for the relatively low number of larger particles present, i.e., the CDNC could be the same for both the first and second scenarios even though the size distributions are quite different between them. (3) Finally, if the precursor aerosol particles within, say, the accumulation mode have sufficiently different composition and resulting hygroscopicity, only the most hygroscopic may initially activate, the less hygroscopic particles only activating as the cloud supersaturation builds to values equal to or greater than their critical supersaturation. This variable hygroscopicity thus leads to a reservoir of buffer particles as in the second scenario except that in this case the buffer consists of less hygroscopic accumulation mode particles rather than smaller (Aitken) particles.

For the data presented here, it is the third scenario that appears to be the most likely explanation for the high $R^{2}$ value for the CDNC-AMNC regression for the following reasons. First, it is noteworthy that the slope of the regression line is $0.72 \pm 0.04$ (intercept of $47 \pm 13$ ) and that, on average, only $\sim 80 \%$ of the AMNC are activated. There is thus a reservoir of unactivated AMNC to act as a buffer for higher cloud supersaturations. Second, in the few cases ( 8 of 47) for which the CDNC actually exceeded the AMNC, it was not by much, on average less that $14 \%$ of the AMNC even though plenty of Aitken particles were present. The excess CDNC constitutes on average only $14 \%$ of the Aitken particle concentration. In agreement with this, a multiple linear regression of CDNC onto both AMNC and Aitken particle concentrations yields an $R^{2}$ of 0.87 , i.e., essentially unchanged from the value for AMNC alone. The AMNC term coefficient or regression slope $(0.66 \pm 0.04)$ and the intercept $(67 \pm 17)$ do not differ from the AMNC-only regression while the Aitken term coefficient is $-0.006 \pm 0.005$, all suggesting a negligible impact by the Aitken mode. Indeed, even if one restricts the regression to only those cases with excess CDNC (i.e., $\mathrm{CDNC}>\mathrm{AMNC}$ ), a similar multiple regression yields an $R^{2}$ of 0.77 , AMNC term coefficient of $0.84 \pm 0.3$, Aitken term coefficient of $0.036 \pm 0.035$ and intercept of $56 \pm 55$. These values indicate that, even for cases in which activation of Aitken particles must be invoked to explain CDNC, only $\sim 4 \%$ of the CDNC form on these particles. On the other hand, it is important to remember that, as with all such empirical relationships, its limiting behavior outside of the data domain from which it derives may be unphysical. For example, as AMNC decreases to zero the CDNC are predicted to limit to the intercept value of $47 \mathrm{~cm}^{-3}$ whereas one would expect on physical principles that the number of Aitken particles activated would increase quite plausibly beyond this number and certainly to a variable degree. Nevertheless, taken together, the regression analyses suggest a negligible role for Aitken particles in our venues and that the larger buffer leading to stability in the CDNC-AMNC relationship is less-hygroscopic accumulation mode particles. Observations of other properties (e.g., hygroscopicity) of the accumulation mode in the stratocumulus venues support this (to be discussed below).

It is commonly asserted that aged atmospheric aerosols, at least within specific size ranges such as the accumulation mode, are internally mixed. However, what is meant by this in the literature is that the individual particles are mixtures of chemical species, many from different sources (e.g., Bi et al., 2011; Li and Shao, 2010; Guazzotti et al., 2001), not that they are of uniform composition. Certainly it has long been known that marine particle composition varies significantly with size (Guazzotti et al., 2001; Neususs et al., 2000; Chuang et al., 2000; Middlebrook et al., 1998) and 


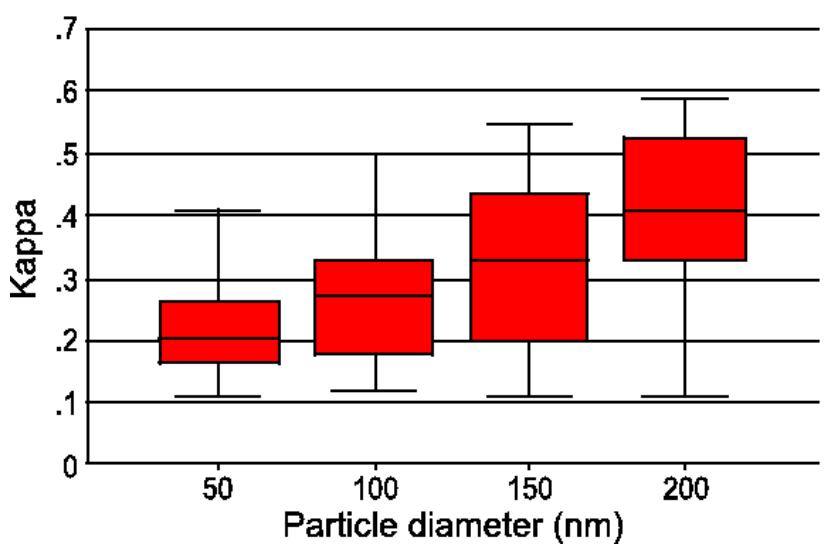

Fig. 4. Variability in the hygroscopicity (quantified by $\kappa$, see text) of aerosols as a function of size observed during CARMA-III in the region of the California cloud deck. Data were from a H-TDMA. The error bars and red boxes denote the $95 \%$ and quartile ranges, respectively, of the measurement population. (Derived from Kaku et al., 2006.)

the individual composition of even similarly sized particles can vary substantially. Such variance leads to variance in the hygroscopicity of atmospheric particles (Pratt and Prather, 2010). Indeed, numerous studies in marine air have demonstrated such variability with size (e.g., Hegg et al., 2008) and even for similarly sized particles (e.g., Swietlicki et al., 2000). Figure 4 illustrates variability in hygroscopicity with size for aerosols in the CARMA operational area (Kaku et al., 2006). The widely used kappa $(\kappa)$ parameter of Petters and Kreidenweis $(2007,2008)$ is employed to quantify the hygroscopicity. Note that the mean and quartile values of hygroscopicity tend to decrease with decreasing size, a relationship that extends well up into the accumulation mode (Hegg et al., 2008). Given that the effective CCN concentration is the sum of all particles activated above a threshold that is commonly at the lower end of the accumulation mode, the observed hygroscopicity variation with size would of itself lead to substantial variability in $\kappa$ and subsequent $\mathrm{CCN}$ activity, thus leading to a substantial $\mathrm{CCN}$ buffer within the accumulation mode. However, other marine data sets have additionally shown variability in the hygroscopicity of particles of precisely the same size as well. An example of this is shown in Fig. 5.

The lower aerosol hygroscopicity at smaller sizes just discussed has important consequences. It likely is due to an enhanced organic presence at the smaller sizes (e.g., Neususs et al., 2000; Pratt and Prather, 2010; Guazzotti et al., 2001) possibly due to the primary particle production process in marine air (e.g., Oppo et al., 1999), offshore advection of pollution (Hawkins et al., 2011), or organic secondary production processes (e.g., Dusek et al., 2010). Another, alternative secondary production possibility that could contribute to the observed hygroscopicity distribution is in-cloud sulfate production. This process can preferentially enhance the

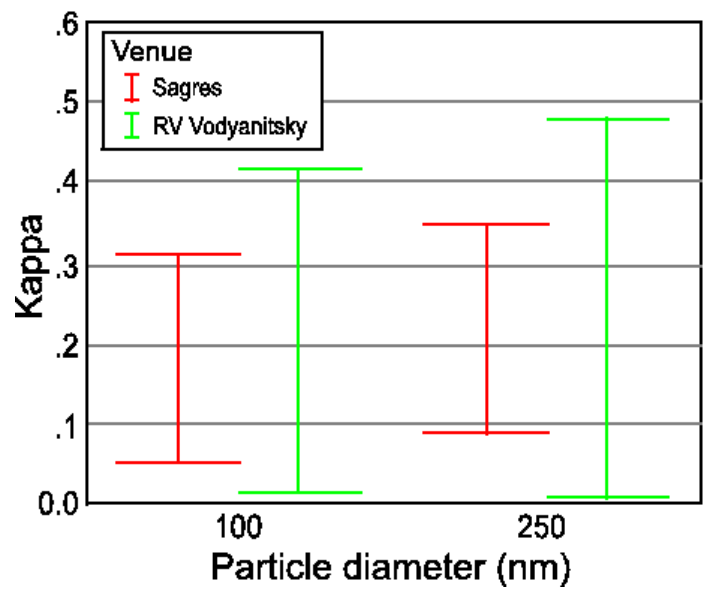

Fig. 5. Variability in aerosol hygroscopicity for particles of the same size. Observations are in marine air in the Eastern Atlantic and are from Swietliki et al. (2000). The error bars represent the range of the measured values.

hygroscopicity of the accumulation mode, which commonly activates in cloud, compared to the Aitken mode, which does not (Hoppel et al., 1990). Hence, this process could provide a positive feedback loop for the relatively high hygroscopicity (and CCN activity) of the AMNC relative to Aitken particles, leading to a gap between the critical supersaturations of Aitken particles and AMNC. In any case, compositional differences suggest that Aitken particles in our venues will be less hygroscopic than those in the accumulation mode, requiring higher supersaturations to activate. This would in turn suggest that less-hygroscopic accumulation mode particles would be a more likely buffer for the CDNC-aerosol relationship than would Aitken particles. This relative favorability is illustrated in Fig. 6, which presents the relationship between critical supersaturation and dry particle diameter parameterized with $\kappa$. Consider a particle of $0.1 \mu \mathrm{m}$ diameter with a $\kappa$ value of 0.3 . Such a particle will have a critical supersaturation of $\sim 0.2 \%$, as shown in the figure. The $\kappa$ value is a reasonable "middle-of-the-road" value (see Fig. 4 and Hudson, 2007). Similarly, a $\kappa$ value of 0.1 is also reasonable for less hygroscopic particles in the accumulation mode range. For a particle of size $0.1 \mu \mathrm{m}$ with a $\kappa$ of 0.1 , activation will occur at a supersaturation of $0.35 \%$, well within the range expected for marine stratocumulus decks (Hudson et al., 2010; Martin et al., 1994). On the other hand, again as shown in Fig. 6, an Aitken mode particle of, say, $0.05 \mu \mathrm{m}$ diameter with the same $\kappa$ of 0.1 would require a supersaturation of $1 \%$ to activate, an unusually high value for stratocumulus. It would require a $\kappa$ value of 0.8 to activate at $0.35 \%$, again as shown in the Figure. Such high $\kappa$ values are rare for such small particles for our venues, as suggested by the data shown in Figs. 4 and 5. Hence, it is more likely that lower hygroscopicity accumulation mode particles will act as the buffer in the CDNC-aerosol relationship than will 


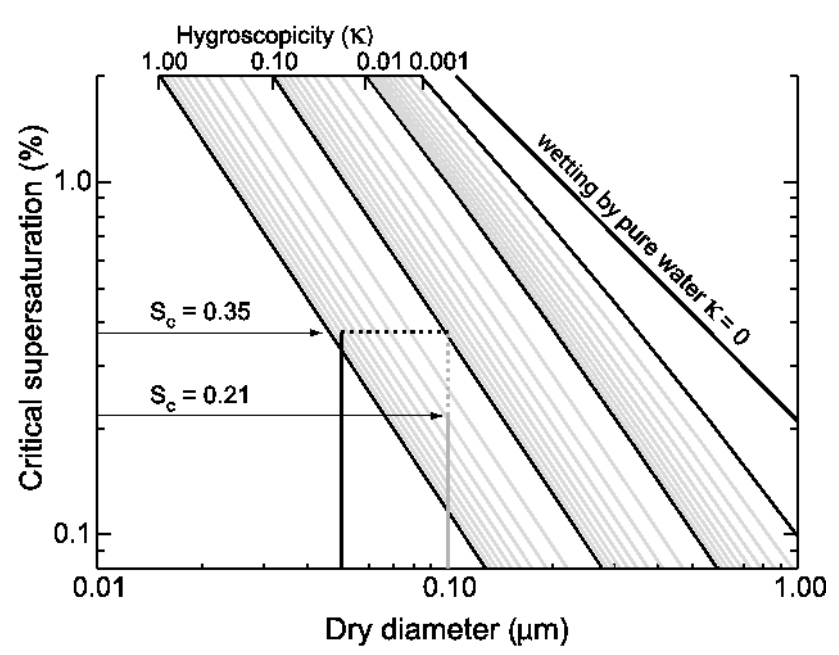

Fig. 6. Diagram illustrating the relationship between size and critical supersaturation $\left(S_{\mathrm{C}}\right)$ as a function of aerosol hygroscopicity $(\kappa)$ for two different particle sizes: one at the low end of the accumulation mode $(0.1 \mu \mathrm{m})$ and one in the Aitken range $(0.05 \mu \mathrm{m})$. (Based on Petters and Kreidenweis, 2007.)

Aitken particles, in accord with the excellent CDNC-AMNC relationship observed. While our analysis has been confined to the three main semi-permanent stratocumulus decks of the earth, The results we present are in general accord with an earlier study (Martin et al., 1994) based partly on data from one of these regions (that of the California deck) but also from stratocumulus from several additional regions (i.e., the mid-Atlantic based on data from the ASTEX experiment as well as from FATE - South Atlantic other than Namibia - and in the general region of the British Isles). These authors do not present quantitative regression analysis for their comparisons of CDNC with AMNC but in their Fig. 8, it is clear that the data for marine air masses would have well fit a linear regression with a slope of $\sim 0.75$ and a small positive intercept, essentially the same result we see for our data.

It is equally noteworthy that data that come from air masses that Martin et al. (1994) characterize as continental would not fit the same relationship and, indeed, show substantially more variance than do the marine data. Nevertheless, they would likely achieve a good linear fit to a different linear function, one with a significantly lower slope. This lower slope may well be associated with drier, warmer continental air rather than with higher aerosol concentrations alone (cf., Brenguier et al., 2003). The latter hypothesis (lower slope due to higher aerosol concentration alone) has been suggested by some earlier studies in which a sublinear relationship between CDMC and AMNC has been advocated due to assumed vapor depletion at higher AMNC (e.g., Chuang et al., 2000). Certainly, all variables other than aerosol concentration being held constant, such a vapor depletion effect must eventually occur, leading to a "role off" in CDNC compared to AMNC. However, the precise location will be a complex function of numerous variables such as the temperature at the lifting condensation level, updraft velocity, the shape and composition of the aerosol size spectrum, etc (cf., Chuang et al., 2000; Leaitch et al., 1996). For example, we note that Bowers et al. (2000) found no evidence of a "role off" for aerosol concentrations until the concentrations (which encompassed both clean marine and continental pollution cases) exceeded $4000 \mathrm{~cm}^{-3}$. On the other hand, $\mathrm{Lu}$ et al. (2008), looking at the CDNC-AMNC relationship in polluted air in the Gulf of Mexico, reported a decrease in activation efficiency in the $400-800 \mathrm{~cm}^{-3}$ AMNC range, about the same as the "role-off" point in Martin et al. Similarly, Leaitch et al. (1986) found a "role-off" point for continental clouds of $\sim 700-800 \mathrm{~cm}^{-3}$ with a slope below this point quite similar to that derived from our data. Raga and Jones (1993) found still lower activation efficiencies and "role-off" in $\mathrm{Cu}$ near Great Britain, though here the finding is likely due in part to sampling near cloud top with consequent entrainment effects.

For our venues, we see neither the decrease in aerosol activation efficiency with size suggested by some earlier studies nor the dichotomy between the efficiency for marine and continental air masses evident in the Martin et al. (1994) data. Though some earlier work done in the California stratocumulus region (Lu et al., 2007) does suggest the possibility of a non-linear relationship, the variable used for sub-cloud aerosol is essentially the $\mathrm{CN}$ concentration rather than the AMNC and a lower slope than we see, particularly at high $\mathrm{CN}$ concentration, is to be expected. On the other hand, the study by Twohy et al. (2005), which did examine the CDNC - AMNC relationship, is entirely consistent with our data, as noted earlier. The Kleinman et al. (2012) study, with somewhat less certainty, also appears consistent. Given this support for our simple relationship, it is important to note that our Sc deck venues experience a wide range of aerosol size distributions and compositions, reflecting the variety of sources that impact them (e.g., Roberts et al., 2006; Hegg et al., 2010; Chand et al., 2010; Hawkins et al., 2010; Haywood et al., 2003), and yet have the relatively uniform activation efficiency illustrated in Fig. 3 of the text. We speculate that a favorable combination of the MBL thermodynamics and dynamics characteristic of Sc decks in our venues likely provides sufficient water vapor for the available AMNC to avoid the depletion phenomenon. However, a quantitative assessment of this issue is beyond the scope of this study. We simply caution, once again, that our results are applicable in principle only to our venues.

\section{Conclusions}

The regression analysis presented here, based on data primarily from the stratocumulus regions off the California and Chilean coasts but with limited additional data from the stratocumulus region off Namibia, suggests that there is a 
simple linear relationship between the peak cloud drop concentration in the stratocumulus decks and the corresponding concentration of accumulation mode particles just below cloud base. The explanation for this relationship is likely the broad range of aerosol hygroscopicity within the accumulation mode, due to the variety of aerosol sources impacting the decks. This results in a buffer of less hygroscopic particles to stabilize the CDNC as per the paradigm noted by Stevens and Feingold (2009). While it is likely that the validity of the derived regression relationship is limited to the regions from which it derives, those regions are the most significant for the indirect forcing of climate by aerosols (e.g., Kogan et al., 1996). Hence, the relationship could be of considerable value in both modeling exercises and remote sensing pertaining to the climate change issue.

Acknowledgements. This study was supported by ONR grant N00014-07-1-0277. We thank Rob Wood for useful comments and discussion. We also thank Richard Leaitch and two other anonymous reviewers for helpful comments.

Edited by: L. M. Russell

\section{References}

Allen, G., Coe, H., Clarke, A., Bretherton, C., Wood, R., Abel, S. J., Barrett, P., Brown, P., George, R., Freitag, S., McNaughton, C., Howell, S., Shank, L., Kapustin, V., Brekhovskikh, V., Kleinman, L., Lee, Y.-N., Springston, S., Toniazzo, T., Krejci, R., Fochesatto, J., Shaw, G., Krecl, P., Brooks, B., McMeeking, G., Bower, K. N., Williams, P. I., Crosier, J., Crawford, I., Connolly, P., Allan, J. D., Covert, D., Bandy, A. R., Russell, L. M., Trembath, J., Bart, M., McQuaid, J. B., Wang, J., and Chand, D.: South East Pacific atmospheric composition and variability sampled along $20^{\circ} \mathrm{S}$ during VOCALS-REx, Atmos. Chem. Phys., 11, 5237-5262, doi:10.5194/acp-11-5237-2011, 2011.

Baumgardner, D., Strapp, W., and Dye, J. E.: Evaluation of the forward scattering aerosol spectrometer probe, Part II: Corrections for coincidence and dead-time losses, J. Atmos. Oceanic Technol., 2, 626-632, 1985.

Bellouin, N., Jones, A., Haywood, J., and Christopher, S. A.: Updated estimate of aerosol direct radiative forcing from satellite observations and comparison against the Hadley Centre climate model, J. Geophys. Res., 113, D10205, doi:10.1029/2007JD009385, 2008.

Bi, X. H., Zhang, G. H., Li, L., Wang, X. M., Li, M., Sheng, G. Y., Fu, J. M., and Zhou, Z.: Mixing state of biomass burning particles by single particle aerosol mass spectrometer in the urban area of PRD, China, Atmos. Environ., 45, 3447-3453, 2011.

Bowers, K. N., Choularton, T. W., Gallagher, M. W., Beswick, K. M., Flynn, M. J., Allen, A. G., Davison, B. M., James, J. D., Robertson, J. L., Harrison, R. M., Hewitt, C. N., Cape, J. N., McFadyen, G. G., Milford, C., Sutton, M. A., Martinsson, B. G., Frank, G., Swietlicki, E., Zhou, J., Berg, O. H., Mentes, B., Papapiropoulos, G., Hansson, H.-C., Leck, C., Kulmala, M., Aalto, P., Vakeva, M., Berner, A., Bizjak, M., Fuzzi, S., Laj, P., Facchini, M.-C., Orsi, G., Ricci, L., Nielsen, M., Allan, B. J., Coe, H., McFiggans, G., Plane, J. M. C., Collett Jr., J. L., Moore, K. F., and Sherman, D. E.: ACE-2 HILLCLOUD, An overview of the ACE-2 ground-based cloud experiment, Tellus B, 52, 750-778, 2000.

Brenguier, J.-L., Pawlowska, H., and Schuller, L.: Cloud microphysical and radiative properties for parameterization and satellite monitoring of the indirect effect of aerosol on climate, J. Geophys. Res., 108, 8632, doi:10.1029/2002JD002682, 2003.

Chand, D., Anderson, T. L., Wood, R., Charlson, R. J., Hu, Y., Liu, Z., and Vaughan, M.: Quantifying above-cloud aerosol using spaceborne lidar for improved understanding of cloudysky direct climate forcing, J. Geophys. Res.,113, D13206, doi:10:10.1029/2007JD009433, 2008.

Chand, D., Hegg, D. A., Wood, R., Shaw, G. E., Wallace, D., and Covert, D. S.: Source attribution of climatically important aerosol properties measured at Paposo (Chile) during VOCALS, Atmos. Chem. Phys., 10, 10789-10801, doi:10.5194/acp-1010789-2010, 2010.

Chuang, P. Y., Collins, D. R., Pawlowska, H., Snider, J. R., Jonsson, H. H., Brenguier, J.-L., Flagan, R. C., and Seinfeld, J. H.: CCN measurements during ACE-2 and their relationship to cloud microphysical properties, Tellus, 52B, 843-867, 2000.

Durkee, P. A., Noone, K. J., Ferek, R. J., Johnson, D. W., Taylor, J. P., Garrett, T. J., Hobbs, P. V., Hudson, J. G., Bretherton, C. S., Innis, G., Frick, G. M., Hoppel, W. A., O’Dowd, C. D., Russell, L. M., Gasparovic, R., Nielsen, K. E., Tessmer, S. A., Ostrom, E., Osborne, S. R., Flagan, R. C., Seinfeld, J. H., and Rand, H.: The Impact of Ship-Produced Aerosols on the Microstructure and Albedo of Warm Marine Stratocumulus Clouds, A Test of the MAST Hypothesis Li and Lii, J. Atmos. Sci., 57, 2554-2569, 2000.

Dusek, U., Frank, G. P., Hildebrandt, L., Curtius, J., Schneider, J., Walter, S., Chand, D., Drewnick, F., Hings, S., Jung, D., Borrmann, S., and Andreae, M. O.: Size matters more than chemistry for cloud-nucleating ability of aerosol particles, Science, 312, 1375-1378, 2006.

Dusek, U., Frank, G. P., Curtius, J., Drewnick, F., Schneider, J., Kurten, A., Rose, D., Andreae, M. O., Borrmann, S., and Pöschl, U.: Enhanced organic mass fraction and decreased hygroscopicity of cloud condensation nuclei $(\mathrm{CCN})$ during new particle formation events, Geophys. Res. Lett., 37, L03804, doi:10.1029/2009GL040930, 2010.

Furutani, H., Dall'osto, M., Roberts, G., and Prather, K. A.: Assessment of the relative importance of atmospheric aging on $\mathrm{CCN}$ activity derived from field measurements, Atmos. Environ. , 42, 3130-3142, 2008.

Gasso, S. and Hegg, D. A.: On the retrieval of columnar aerosol mass and CCN concentration by MODIS, J. Geophys. Res., 108, 4010, doi:10.1029/2002JD002382, 2003.

Guazzotti, S. A., Coffee, K. R., and Prather, K. A.: Continuous measurements of size-resolved particle chemistry during INDOXIntensive Field Phase 99, J. Geophys. Res., 106, 28607-28627, 2001.

Hawkins, L. N., Russell, L. M., Covert, D. S., Quinn, P. K., and Bates, T. S.: Carboxylic acids, sulfates, and organosulfates in processed continental organic aerosol over the southeast $\mathrm{Pa}$ cific Ocean during VOCALS-Rex 2008, J. Geophys. Res., 115, D13201, doi:10.1029/2009JD013276, 2010.

Haywood, J. M., Osborne, S. R., Francis, P. N., Keil, A., Formenti, P., Andreae, M. O., and Kaye, P. H.: The mean physical and 
optical properties of regional haze dominated by biomass burning aerosol measured from the C-130 aircraft during SAFARI 2000, J. Geophys. Res., 108, D138473, doi:10.1029/2002JD002226, 2003.

Hegg, D. A., Nielsen, K., Covert, D. S., Jonsson, H. H., and Durkee, P. A.: Factors influencing the mesoscale variations in marine stratocumulus albedo, Tellus B, 59, 66-76, 2007.

Hegg, D. A., Covert, D. S., and Jonsson, H. H.: Measurements of size-resolved hygroscopicity in the California coastal zone, Atmos. Chem. Phys., 8, 7193-7203, doi:10.5194/acp-8-7193-2008, 2008.

Hegg, D. A., Covert, D. S., Jonsson, H. H., and Woods, R.: Differentiating natural and anthropogenic cloud condensation nuclei in the California coastal zone, Tellus B, 61, 669-676, 2009.

Hegg, D. A., Covert, D. S., Jonsson, H. H., and Woods, R. K.: The contribution of anthropogenic aerosols to aerosol light-scattering and CCN activity in the California coastal zone, Atmos. Chem. Phys., 10, 7341-7351, doi:10.5194/acp-10-7341-2010, 2010.

Henning, S., Wex, H., Henning, T., Kislev, A., Snider, J. R., Rose, D., Dusek, U., Frank, G. P., Poschl, U., Kristensson, A., Bilde, M., Tillman, R., Kiendler-Schnarr, A., Mentel, T. F., Walter, S., Schneider, J., Wennrich, C., and Stratmann, F.: Soluble mass, hygroscopic growth, and droplet activation of coated soot particles during LACIS Experiment in November (LexNo), J. Geophys. Res., 115, D11206, doi:10.1029/2009JD012626, 2010.

Hudson, J. G.: Effects of CCN concentration on stratus clouds, J. Atmos. Sci., 40, 480-486, 1983.

Hoppel, W., Fitzgerald, J., Frick, G., Larson, R., and Mack, E: Aerosol size distributions and optical properties found in the marine boundary layer over the Atlantic Ocean, J. Geophys. Res., 95, 3659-3686, doi:10.1029/JD095iD04p03659, 1990.

Hudson, J. G.: Variability of the relationship between particle size and cloud-nucleating ability, Geophy. Res. Lett., 34, L08801, doi:10.1029/2006GL028850, 2007.

Hudson, J. G. and Noble, S.: CCN and cloud droplet concentrations at a remote ocean site, Geophys. Res. Lett., 36, L13812, doi:10.1029/2009GL038465, 2009.

Hudson, J. G., Noble, S., and Jha, V.: Stratus cloud supersaturations, Geophys. Res. Lett., 37, L21813, doi:10.1029/2010GL045197, 2010.

Huneeus, N., Gallardo, L., and Rutllant, J. A.: Offshore transport episodes of anthropogenic sulfur in Northern Chile: potential impact on the stratocumulus cloud deck, Geophys. Res. Lett., 33, L19819, doi:10.1029/2006GL026921, 2006.

IPCC, Climate Change: The Scientific Basis: contributions of Working Group I to the Third Assessment Report of the IPCC, edited by: Houghton, J. T., Ding, Y., Griggs, D. J., Noguer, M., van der Linden, P. J., Dai, X., Maskell, K., and Johnson, C. A., Cambridge University Press, New York, 881 pp., 2001.

IPCC, Climate Change: The Physical Science Basis: contribution of Working Group 1 to the Fourth Assessment Report of the IPCC, edited by: Solomon, S., Qin, D., Manning, M., Chen, Z., Marquis, M., Averyt, K. B., Tignor, M., and Miller, H. L., Cambridge University Press, New York, 996 pp., 2007

Jurányi, Z., Gysel, M., Weingartner, E., DeCarlo, P. F., Kammermann, L., and Baltensperger, U.: Measured and modelled cloud condensation nuclei number concentration at the high alpine site Jungfraujoch, Atmos. Chem. Phys., 10, 7891-7906, doi:10.5194/acp-10-7891-2010, 2010.
Kaku, K. C., Hegg, D. A., Covert, D. S., Santarpia, J. L., Jonsson, H., Buzorius, G., and Collins, D. R.: Organics in the Northeastern Pacific and their impacts on aerosol hygroscopicity in the subsaturated and supersaturated regimes, Atmos. Chem. Phys., 6, 4101-4115, doi:10.5194/acp-6-4101-2006, 2006.

Kapustin, V. N., Clarke, A. D., Shinozuka, Y., Howell, S., Brekhovskikh, Nakajima, T., and Higurashi, A.: On the determination of cloud condensation nuclei from satellites: challenges and possibilities, J. Geophys. Res., 111, D04202, doi:10.1029/2004JD005527, 2006.

Keil, A. and Haywood, J. M.: Solar radiative forcing by biomass burning aerosol particles during SAFARI 2000: a case study based on measured aerosol and cloud properties, J. Geophys. Res., 108, 8467, doi:10.1029/2002JD002315, 2003.

Klein, S. A. and Hartmann, D. L.: The seasonal cycle of low stratiform clouds, J. Climate, 6, 1587-1606, 1993.

Kleinman, L. I., Daum, P. H., Lee, Y.-N., Lewis, E. R., Sedlacek III, A. J., Senum, G. I., Springston, S. R., Wang, J., Hubbe, J., Jayne, J., Min, Q., Yum, S. S., and Allen, G.: Aerosol concentration and size distribution measured below, in, and above cloud from the DOE G-1 during VOCALS-REx, Atmos. Chem. Phys., 12, 207-223, doi:10.5194/acp-12-207-2012, 2012.

Kogan, Z. N., Kogan, Y. L., and Lilly, D. K.: Evaluation of sulfate aerosols indirect effect in marine stratocumulus clouds using observation-derived cloud climatology, Geophys. Res. Lett., 23, 1937-1940, 1996.

Leaitch, W. R., Banic, C. M., Isaac, G. A., Couture, M. D., Liu, P. S. K., Gultepe, I., and Li, S.-M.: Physical and chemical observations in marine stratus during the 1993 North Atlantic Regional Experiment: Factors controlling cloud drop number concentrations, J. Geophys. Res., 101, 29123-29135, 1996.

Li, W. J. and Shao, L. Y.: Mixing and water-soluble characteristics of particulate organic compounds in individual urban aerosol particles, J. Geophys. Res., 115, D02301, doi:10.1029/2009JD012575, 2010.

Lu, M.-L., Conant, W. C., Jonsson, H. H., Varutbangkul, V., Flagan, R. C., and Seinfeld, J. H.: The Marine Stratus/Stratocumulus Experiment (MASE): Aerosol-cloud relationships in marine stratocumulus, J. Geophys. Res., 112, D10209, doi:10.1029/2006JD007985, 2007.

Lu, M.-L., Feingold, G., Jonsson, H. H., Chuang, P. Y., Gates, H., Flagan, R. C., and Seinfeld, J. H.: Aerosol-cloud relationship in continental shallow cumulus, J. Geophys. Res., 113, D15201, doi:10.1029/2007JD009254, 2008.

Martin, G. M., Johnson, D. W., and Spice, A.: The measurement and parameterization of effective radius of droplets in warm stratocumulus clouds, J. Atmos. Sci., 51, 1823-1842, 1994.

McFiggans, G., Artaxo, P., Baltensperger, U., Coe, H., Facchini, M. C., Feingold, G., Fuzzi, S., Gysel, M., Laaksonen, A., Lohmann, U., Mentel, T. F., Murphy, D. M., O’Dowd, C. D., Snider, J. R., and Weingartner, E.: The effect of physical and chemical aerosol properties on warm cloud droplet activation, Atmos. Chem. Phys., 6, 2593-2649, doi:10.5194/acp-6-2593-2006, 2006.

Middlebrook, A. M., Murphy, D. M., and Thomson, D. S.: Observations of organic material in individual marine particles at Cape Grim during the First Aerosol Characterization Experiment (ACE-1), J. Geophys. Res., 103, 16475-16483, 1998.

Neususs, C., Pelzing, M., Plewka, A., and Herrmann, H.: A 
new analytical approach for size-resolved speciation of organic compounds in atmospheric aerosol particles: Methods and first results, J. Geophys. Res., 105, 4513-4527, doi:10.1029/1999JD901038, 2000.

Oppo, C., Bellandi, S., Innocenti, N. D., Stortini, A. M., Loglio, G., Schiavuta, E., and Cini, R.: Surfactant components of marine organic matter as agents for biogeochemical fractionation and pollutant transport via marine aerosols, Mar. Chem., 63, 235253, 1999.

Petters, M. D. and Kreidenweis, S. M.: A single parameter representation of hygroscopic growth and cloud condensation nucleus activity, Atmos. Chem. Phys., 7, 1961-1971, doi:10.5194/acp-71961-2007, 2007.

Petters, M. D. and Kreidenweis, S. M.: A single parameter representation of hygroscopic growth and cloud condensation nucleus activity - Part 2: Including solubility, Atmos. Chem. Phys., 8, 6273-6279, doi:10.5194/acp-8-6273-2008, 2008.

Platnick, S. and Twomey, S.: Determining the susceptibility of cloud albedo to changes in droplet concentration with the Advanced Very High Resolution Radiometer, J. Appl. Meteor., 33, 334-347, 1994

Pratt, K. A. and Prather, K. A.: Aircraft measurements of vertical profiles of aerosol mixing states, J. Geophys. Res., 115, D11305, doi:10.1029/2009JD013150, 2010.

Pringle, K. J., Carslaw, K. S., Spracklen, D. V., Mann, G. M., and Chipperfield, M. P.: The relationship between aerosol and cloud drop number concentrations in a global aerosol microphysics model, Atmos. Chem. Phys., 9, 4131-4144, doi:10.5194/acp-94131-2009, 2009.

Remer, L. A., Kaufman, Y. J., Tanre, D., Mattoo, S., Chu, D. A., Martins, J. V., Li, R.-R., Ichoku, C., Levy, R. C., Kleidman, R. G., Eck, T. F., Vermote, E., and Holben, B. N.: The MODIS aerosol algorithm, products, and validation, J. Atmos. Sci., 62, 947-973, 2005.
Roberts, G., Mauger, G., Hadley, O., and Ramanathan, V.: North American and Asian aerosols over the eastern Pacific Ocean and their role in regulating cloud condensation nuclei, J. Geophys. Res., 111, D13205, doi:10.1029/2005JD006661, 2006.

Stevens, B. and Feingold, G.: Untangling aerosol effects on clouds and precipitation in a buffered system, Nature, 461, 607-613, 2009.

Swietlicki, E., Zhou, J., Covert, D. S., Hameri, K., Busch, B., Vakeva, M., Dusek, U., Berg, O. H., Widensohler, A., Aalto, P., Makela, P., Martinsson, B. G., Papaspiropoulos, G., Mentes, B., Frank, G., and Stratmann, F.: Hygroscopic properties of aerosol particles in the northeastern Atlantic during ACE-2, Tellus B, 52, 201-227, 2000.

Twohy, C. H., Petters, M. D., Snider, J. R., Stevens, B., Tahnk, W., Wetzel, M., Russell, L., and Burnet, F.: Evaluation of the aerosol indirect effect in marine stratocumulus clouds: droplet number, size, liquid water path, and direct radiative impact, J. Geophys. Res., 110, D08203, doi:10.1029/2004JD005116, 2005.

Twomey, S.: The nuclei of natural cloud formation, II: The supersaturation in natural clouds and the variation of cloud droplet concentration, Pure Appl. Geophys., 43, 243-249, 1959.

Wang, J., Flagan, R. C., Seinfeld, J. H., Jonsson, H. H., Collins, D. R., Russell, P. B., Schmid, B., Redemann, J., Livingston, J. M., Gao, S., Hegg, D. A., Welton, E. J., and Bates, D.: Clearcolumn radiative closure during ACE-Asia: Comparison of multiwavelength extinction derived from particle size and composition with results from Sun photometry, J. Geophys. Res., 107, 4688, doi:10.1029/2002JD002465, 2002.

Wang, J., Daum, P. H., Kleinman, L. I., Lee, Y. N., Schwartz, S. E., Springston, S. R., Jonsson, H., Covert, D., and Elleman, R.: Observation of ambient aerosol particle growth due to in-cloud processes within boundary layers, J. Geophys. Res., 112, D14207, doi:10.1029/2006JD007989, 2007.

Warren, S. G., Hahn, C. J., London, J., Chervin, R. M., and Jenne, R. L. : Global Distribution of Total Cloud Cover and Cloud type Amounts Over the Ocean, NCAR Technical Note NCAR/TN317+STR, 1988. 